\title{
Меланхолия приходит в Россию. Монастыри как долгаузы в России в XVIII веке
}

\section{Melancholia Arrives in Russia: Monasteries as Asylums in Eighteenth-Century Russia}

\author{
Екатерина Махотина \\ Боннский университет \\ Ekaterina Makhotina \\ The University of Bonn \\ emakhotina@uni-bonn.de
}

\begin{abstract}
:
Western historiography about the history of madness has pointed out that the emergence and active use of special medical terms led to the development of certain discourses on disease which had been appropriated and used on a subjective level. The discourse on melancholy is such a case. And it may seem surprising that the history of melancholy has remained a West European phenomenon until this day: For Russia, there are no studies on melancholy as illness, sin of acedia or social deviance in the eighteenth century. This article aims to close this gap and systemize melancholics from the point of view of the state, clerical actors and society. With this in mind this article will observe a special socio-cultural phenomenonthe confinement of the so-called "izumlennye," or "madmen" in monasteries, which were similar to west European institutions that functioned using internment, punishment and discipline. This article will address the following aspects of the melancholy discourse: 1) Madness as a security issue: Internment of the "mad" in severe monastery prisons; 2) Melancholy as illness and self-diagnosis: Melancholy as a reason for the reduction of punishment; 3) Melancholy as external diagnosis in family conflicts and the argument for sending "mentally sick" relatives to the monastery; and, finally, 4) Religious melancholy: those who doubted their own faith and went to repent in a monastery.
\end{abstract}

Ключевые слова:

меланхолия, душевные болезни, монастыри, ссылка, заключение, наказание, медицинский дискурс, история менталитетов, религия, право, социальная история России XVIII века, семейные конфликты

Keywords:

melancholia, mental disease, monasteries, confinement, punishment, medical discourse, mentalities in Russia, religion, justice, social history in Russia, family conflicts

\section{Введение}

В начале декабря 1723 года Синоду были предоставлены письма иеромонаха Иллариона, в которых тот бранил Бога, богородицу и угодников, а также государя 
и государыню, “скверными словами.”' Как и полагается в таких случаях, ${ }^{2}$ Синод переслал эти письма в Тайную Канцелярию, сопроводив, однако, их запиской, что писаны они “в меленхолии." Синод определил Иллариона под арест “до исправления ума” в Александро-Невский монастырь, приставив к нему монаха “доброжительного, дабы он, Илларион, ко всякому церковному служению ходил не леностно." От настоятеля монастыря требовались регулярные отчеты о состоянии Иллариона и немедленный доклад, “как он от болезни свободен будет.” За время его пребывании на исправлении, на Иллариона жаловались приставленный к нему наставник-иеромонах и соседи по келье (“в келье утеснение”), за что на него сначала были наложены “железа," а затем его отправили в другой монастырь. В Иверском монастыре его забыли на следующие двадцать лет и лишь в 1743 году по требованию Синода, настоятель Иверского монастыря дал знать, что Илларион обретается в монастырской больнице, и “так как уже двадцать лет от меленхолии не свободен, то и впредь к освобождению от оной безнадежен."5

Этот эпизод погружает нас в историю душевных заболеваний в России в XVIII веке. Илларион, монах Александро-Невского Монастыря в Петербурге, стал одним из первых “меленхоликов,” т.е. признанным “одержимым болезнью," которая объясняет проступки и смягчает наказание. Стоит напомнить, что случаи богохульства и оскорбления величества карались в России смертной казнью, поэтому смягчение наказания - приговор к ссылке в монастырь - было существенным.

Но что означает “меланхолия" в России раннего нового времени и каким образом меланхолия связана с историей монастырей? До сих пор исследования по истории меланхолии в России в основном рассматривали ее как культурную идиому в эпоху модерна. ${ }^{6}$ Меланхолия связывается с культом гениальности,

\footnotetext{
${ }^{1}$ Илларион (мирское имя - Иосиф) был назначен в 1721 году в число иеромонахов Ревельской флотилии. Автор благодарит анонимного рецензента за это примечание и ссылку на работу С. Рункевич, Александро-Невская Лавра, 1713-1913 (Санкт-Петербург: Синодальная тип., 1913), 207-208, где описывается дело Иллариона. (S. Runkevich, Aleksandro-Nevskaia Lavra, 1713-1913 (St. Petersburg: Sinodal'naia tip., 1913), 207-208). Благодарность высказывается обоим анонимным рецензентам при подготовке статьи к публикации в Вивлиофике, а также Сергею Шаляпину (Архангельск) за чтение и критику статьи в процессе ее написания.

Об обращении с богохульниками см.: Е. Смилянская, Волшебники, богохульники, еретики. Народная религиозность и “духовные преступления" в России XVIII века (Москва: Индрик, 2003). (Е. Smilianskaia, Volshebniki, bogokhul'niki, eretiki. Narodnaia religioznost' i "dukhovnye prestupleniia" $v$ Rossii XVIII veka (Moscow: Indrik, 2003).

3 Дело монаха Иллариона, писавшего в меланхолии. Российский Государственный Исторический Архив (РГИА), ф. 796, оп.4, д. 583, л.4. 1723 год. (Rossiiskii Gosudarstvennyi Istoricheskii Arkhiv (RGIA), f. 796, op. 4, d. 583, 1. 4. 1723 god.). Примечание автора: курсив в цитатах здесь и далее - мой.

${ }^{4}$ Там же, л. 6. (Tam zhe, 1. 6.)

${ }^{5}$ Там же, л.28. (Tam zhe, 1. 28)

${ }^{6}$ М. Стейнберг, "Меланхолия Нового времени: дискурс о социальных эмоциях между двумя революциями," в Российская Империя чувств: Подходы к культурной истории змоций, ред. Я. Плампер, Ш. Шахадат и М. Эли (Москва: Новое литературное обозрение, 2010), 202-226. (М. Steinberg, "Melankholiia Novogo vremeni: diskurs o sotsial'nykh emotsiiakh mezdhu dvumia revoliutsiiami," v Rossiiskaia Imperiia chuvstv: Podkhody k kul'turnoi istorii emotsii, red. Ia. Plamper, Sh. Shakhadat i M. Eli (Moscow: Novoe literaturnoe obozrenie, 2010), 202-226).
} 


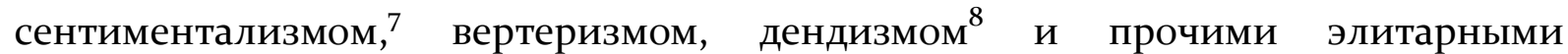
феноменами культуры, проявляющимися в литературе и эго-документах XIX века. ${ }^{9}$ Это, пользуясь определением Карин Юханиссон, ${ }^{\text {10 }}$ - “серая меланхолия," т.е. меланхолия в своей амбивалентности, когда психические страдания связываются с необыкновенной творческой силой и гениальностью. Так, уже хорошо изучена меланхолия как культурная метафора в литературе Нового времени (начиная с Карамзина и заканчивая Достоевским) ${ }^{11}$ и автобиографического письма (Андрей Тургенев). ${ }^{12}$ Однако патологический облик меланхолии, - “черная меланхолия,” и её формы, также как и врачевание, до сих пор оставались вне внимания исследователей.

В процессе архивной работы о монастырской ссылке в XVIII веке, мое внимание привлекла “болезнь меленколия": удивительно, как часто меланхолики становились узниками (или “пациентами”) монастырей. В этой статье на материале впервые введенных в оборот архивных источников делается попытка разобраться в непростой взаимосвязи между меланхолией и монастырским заключением. Для этого выявлены типичные случаи использования этого понятия в судебной практике, ее удивительная сплетённость с политическим или религиозным кризисом, а также практики “врачевания" болезни. Насколько судебные практики отражали общие социальные изменения по отношению к заключенным в России переходной эпохи? Когда и почему практика заключения, изоляции и “смирения" безумных сменилась практикой “человеколюбивого исправления”? Как проявлялась связь религии с дискурсом о меланхолии? В фокусе этой статьи - еще не исследованный аспект истории обращения с душевными болезнями и формами отклонения от социальных и религиозных норм поведения в России XVIII века, связанный с историей монастырского заключения.

Вначале важно оговориться что ссылка "меланхоликов" в монастыри не была массовым явлением. Как и на Западе, ссылка и изоляция “безумных” в различных учреждениях не было “великим пленением,” как его определил Мишель Фуко в хорошо известной “Истории безумия в классическую эпоху." ${ }^{13}$ Но это не уменьшает важность исследовательского вопроса: изменение в отношении к душевно

\footnotetext{
${ }^{7}$ Gudrun Langer, "Der Melancholie-Begriff des russischen Sentimentalismus und der Frühromantik," in Russische Begriffsgeschichte der Neuzeit. Beiträge zu einem Forschungsdesiderat, ed. Peter Thiergen (Cologne: Böhlau Verlag, 2006), 233-269.

${ }^{8}$ Юрий Лотман, “Русский дендизм,” в Беседы о русской культуре (Москва: Азбука Аттиус, 2015), 180197. (Iurii Lotman, "Russkii dendizm," v Besedy o russkoi kul'ture (Moscow: Azbuka Attius, 2015), 180-197). ${ }^{9}$ Alexander Kraus, "Erlesene Gefühlswelten Emotionale Wirklichkeiten des Andrej Timofeevic Bolotov," in Vom Wir zu Ich. Individuum und Autobiographik im Zarenreich, eds. Julia Herzberg \& Christoph Schmidt (Cologne: Böhlau Verlag, 2007), 109-147.

${ }^{10}$ Карин Юханнисон, История меланхолии. О страхе, скуке и чувствительности в прежние времена и теперь (Москва: Новое литературное обозрение, 2011), 44-45. (Karin Iukhannison, Istoriia melankholii. O strakhe, skuke i chuvstvitel'nosti v prezhnie vremena i teper' (Moscow: Novoe literaturnoe obozrenie, 2011), 44-45.

${ }^{11}$ Isabelle Guntermann, Mysterium Melancholie: Studien zum Werk Innokentij Annenskijs (Köln: Böhlau Verlag, 2001).

${ }^{12}$ Андрей Зорин, Появление героя: Из истории русской эмоциональной культуры конца XVIII начала XIX века (Москва: Новое литературное обозрение, 2016). (Andrei Zorin, Poiavlenie geroia: Iz istorii russkoi emotsional'noi kul'tury kontsa XVIII - nachala XIX veka (Moscow: Novoe literaturnoe obozrenie, 2016)).

${ }^{13}$ Michel Foucault, Wahnsinn und Gesellschaft: Eine Geschichte des Wahns im Zeitalter der Vernunft (Frankfurt a. M.: Suhrkamp, 2015), 99-128.
} 
больным отражает важную трансформацию “климата менталитетов” (mentality clima, Pieter Spierenburg. $)^{14}$

Понятие меланхолии в России отличается - как и в Европе - широким спектром возможных определений ее симптомов. Ни в источниках современников Западной Европы, ни в российских документах нет четкого разделением между безумием, душевной болезнью, манией, буйством, “неправильным” темпераментом и подавленным состоянием. Известно выражение Роберта Бертона, автора знаменитой Анатомии меланхолии: “The Tower of Babel never yielded such confusion of tongues as this Chaos of Melancholy doth variety of symptoms." 15 Так, в судебных практиках XVIII века у термина меланхолия широкий спектр значений: это и сумасбродство, и одержимость, и бесчинное поведение, и тоска, сопровождаемая делириумом, и множество других понятий, связанных с “изумлением," т.е. отсутствием разума. ${ }^{16}$ Поэтому в этой статье понятие меланхолии используется в широком смысле, а отправной точкой служит феномен помешательства. Меланхолики - это те же "сумасброды," “изумленные” (далее - без кавычек), “умалишенные,” “помешанные.” Наше современное бытовое понятие меланхолии как печальной депрессии, эндогенного психического расстройства не может быть применимо к XVIII веку и пониманию душевных болезней того времени. Лишь в XIX веке меланхолия стала “модной тоской,” отразившейся в мемуарах и других эго-документах аристократии. Именно в дискуссии разнообразия обликов меланхолии, а не в попытке четкой классификации понятий, связанных с душевными заболеваниями и заключается смысл данной статьи.

Этот фокус определяет и структуру исследования: Следуя вступительном анализу понятия меланхолия в Европе, в этой статье последовательно рассмотрены различные формы проявления безумия в России и различные функции дискурса о меланхолии, - меланхолия как медицинский дискурс помрачения ума и юридическая проблема, - которые оказываются в непосредственной связи с монастырским заключением, широко практиковавшимся в XVIII веке. Каким бы ни был облик меланхолика, являющийся нам в судебных документах петербургской эпохи, к нему применялась одна практика: ссылка в монастырь.

Какую роль играли монастыри для решения социальных вопросов курса Gute Policey? В чем заключалась общественная составляющая “исправления” - какую роль играли челобитные подданных в применении монастырского заключения для тех, кто выбивался из принятых поведенческих норм? Какие практики монастырского заключения должны были “исцелить” или исправить безумца? Насколько успешными были они?

\footnotetext{
${ }^{14}$ Pieter Spierenburg, The Prison Experience: Disciplinary Institutions and their Inmates in Early Modern Europe (Amsterdam: Amsterdam University Press, 2007).

${ }^{15}$ Цит. по Jennifer Radden, ed., The Nature of Melancholy: From Aristotle to Kristeva (Oxford: Oxford University Press, 2000), 5.

${ }^{16}$ Лия Янгулова, “Институционализация психиатрии в России. Генеалогия практик свидетельства и описания безумия. Конец XVII-XIX вв.," (Рукопись автореферата диссертации, Вышая школа экономики 2004), 120. (Liia Iangulova, "Institutsionalizatsiia psikhiatrii v Rossii. Genealogiia praktik svidetel'stva i opisaniia bezumiia. Konets XVII-XIX vv.," (Rukopis' avtoreferata Dissertatsii Vyshaia shkola ekonomiki, 2004), 120).
} 


\section{Фундамент: понятие меланхолии в Западной Европе}

До того, как меланхолия пришла в Россию в XVIII веке, она уже пару веков была литературной метафорой в Западной Европе, описанная Шекспиром или Тирсо де Молиной. В Англии Елизаветинской эпохи элитарное уныние культивировалось в аристократических кругах благодаря широкой известности труда Марсилио Фичино "De vita triplici“ (1482-89). ${ }^{17}$ Фичино определил humor melancholicus, меланхолический гумор, как телесную причину для божественного откровения и просветления. ${ }^{18}$ Опираясь на "Проблемату XXX, 1" Аристотеля, Фичино еще раз описал теорию естественной взаимосвязи четырех гуморов в человеческом организме с особенным божественным творческим даром. Аристотельский постулат, о том, что лучшие и мужественнейшие мыслители и правители меланхолики, сделал европейскую культурную элиту эпохи позднего гуманизма поклонниками "модной" болезни меланхолии. ${ }^{19}$ Фичино вывел меланхолию из распространённого в поздней античности и в средневековье негативнопатологической интерпретации, где черная желчь вызывает болезненные симптомы и приводит к безумию. ${ }^{20}$

Средневековая медицина “лечила” меланхолию античными методами. Так, настоятельница одного из бенедектинских монастырей Хильдегарда фон Бинген (1098-1179), первая женщина-медик, чьи трактаты были опубликованы, в книге Liber compositae medicinae рассматривает и меланхолию. ${ }^{21}$ Ее понимание болезни и рецепты отражают знание о распространенных монашеских практиках того времени, где достаточно четко проявляется связь медицинского учения Гиппократа с религиозным, теологическим объяснением болезни. Хильдегарда объясняла душевные расстройства первородным грехом и дополняла это объяснение античными воззрениями о гуморах. Пока человек физически здоров, он не замечает склонность к меланхолии. Меланхолия всегда может стать болезнью, если равновесие гуморов нарушится - это приводит к мигрени, рассеянности, и, в итоге, к безумию. Меланхолия может быть смягчена быстрым вмешательством - подогретым вином, подавляющим влияние желчи, травами. Особенностью медицинского дискурса средневековой Европы являлось то, что медики соглашались с богословами в том, что меланхолия являлась средой,

\footnotetext{
${ }^{17}$ Bridget Gellert Lyons, Voices of Melancholy: Studies in Literary Treatments of Melancholy in Renaissance England (London: Routledge, 1971).

${ }^{18}$ Marsilio Ficino, Three Books of Life, ed. Carol V. Kaske \& John Clark (Binghampton, NY: Medieval \& Renaissance Texts \& Studies, 1989).

${ }^{19}$ Исследователи указывают на влияние гравюры Дюрера “Меланхолия” (1514) на распространение тоски как автобиографической интерпретационной модели для королевской знати. См. K. Giehlow, Dürers Stich 'Melencolia' und der maximilianische Humanistenkreis, in Mitteilungen der Gesellschaft für verfieltigände Kunst (1904); развернутый анализ см., Raymond Klibansky, Erwin Panofsky \& Fritz Saxl, Saturn und Melancholie. Studien zur Geschichte der Naturphilosophie und Medizin, der Religion und der Kunst (Frankfurt a.M.: Suhrkamp, 2015), 397-557.

${ }^{20}$ Особенно салернская школа медицины в средневековой Европы сделала меланхолию сборным понятием для спектра психопатологических явлений, которые простой народ понимал как одержимость бесами. Carlos Watzka, Vom Hospital zum Krankenhaus: Zum Umgang mit psychisch und somatisch Kranken im frühneuzeitlichen Europa (Vienna: Böhlau Verlag, 2005), 16.

${ }^{21}$ Hildegard von Bingen, Book of Holistic Healing. цит. по Radden, The Nature of Melancholy, 84-85.
} 
способствующей проявлению злого духа. Страдание от меланхолии - это работа дьявола, а не испытание, посылаемое Богом свыше. ${ }^{22}$

Христианская культура средневековья дала начало и сохранила идею о психических расстройствах, как о заболевании, не имеющем органических причин. ${ }^{23}$ В средневековой традиции безумие интерпретировалось как наказание за грех, а сам грех - как душевная болезнь. Известно положение Лютера о том, что болезнь разума вызвана сатаной. Так, в Германии XVI века связь религии и душевных расстройств отражалась в понимании, что болезнь душевная часто приводит к проступкам религиозного (богохульного) характера, так как больная меланхолией душа является “купальней дьявола - melancholia balneum diaboli” и лечится, кроме трав, духовным окормлением (регулярные молитвы, хождение на божественные службы) и трудом.

Монастырские медики и простые монахи часто размышляли о меланхолии в своих трактатах о возможности исцеления. Здесь поддерживалось стандартное объяснение, что меланхолия (помутнение разума) приходит от дьявола. Например, известная Тереза Авильская (1573-1582) в рассуждении о меланхолии монахинь писала: “я уверена в том, что дьявол использует меланхолию как средство, чтобы победить человека.” 24

Дуализм интерпретационной модели Гиппократа и Аристотеля придает меланхолии в Европе XVI-XVII веков интересное многообразие, включающее в себя и фигуру “меланхолического короля" и его придворного клоуна. В главном труде этой эпохи о меланхолии, книге писателя и теолога Роберта Бертона “Анатомия меланхолии” (1621), меланхолия представляется определяющей жизненной силой. Психофизиология гуморов и темпераментов выступает в качестве организующего принципа человеческого общества, способствуя психологизации картины мира. Бертон передал этим Zeitgeist эпохи: индивидуализация, секуляризация и конфессионализация, потеря привычного религиозного порядка и поддержки. ${ }^{25}$ Учение Реформации, объявив изначальную испорченность и греховность человека, отняло у своих подданных возможность теологического объяснения различных несчастий. Меланхолия проявляется здесь

\footnotetext{
${ }^{22}$ Жан Старобински отмечает для средневекового дискурса о меланхолии нерешенность вопроса о том, стал ли он жертвой злых чар (демона) или сам поддался влиянию своего темперамента. Жан Старобински, Чернила меланхолии. (Москва: Новое литературное обозрение, 2016), 231. (Zhan Starobinski, Chernila melankholii (Moscow: Novoe literaturnoe obozrenie, 2016), 231).

${ }^{23}$ См. исследование о безумии в Германии 16 века: Н. C. Erik Midelfort, A History of Madness in the Sixteenth-Century Germany (Stanford: Stanford University Press, 1999), 9, или например связь “гуморальной меланхолии” с первородным грехом у Хильдегарды Бингенской, см. выше. См. также Старобински, Чернила, 231. Это, однако, не значит, что средневековая медицина сводилась к изгнанию злых духов. Лекари предлагали множество методик врачевания и рецептов восточного, античного или арабского происхождения, а в некоторых случаях расстройства лечили античным способом восстановления баланса гуморов - кровопусканием, стимулированием потоотделения, очищением организма через слабительные или средства, вызывающие рвоту. См. Старобински, Чернила, 44-48, 58-63.

${ }^{24}$ В качестве лечения Тереза предлагала жесткое смирение. Те монахи и монахини, сохранившие остатки светлого разума, подлежали жесткому обращению (смирению), подобно дисциплинарным отступникам; те же, кто потерял разум совсем, не должны быть наказаны, так как их постоянное исступление уже являлось жестоким штрафом. Teresa of Avila, The Foundations (1573-1582). цит. по Radden, The Nature of Melancholy, 109.

${ }^{25}$ Harald Tersch, "Melancholie in österreichischen Selbstzeugnissen des Späthumanismus," Mitteilungen des Instituts für österreichische Geschichtsforschung, 105 (1997), 131-132.
} 
в своей роли как сдерживающая, тормозящая активную деятельность сила, постулирующая vita contemplativa вместо vita activa.

То, что грех и безумство были важными темами европейского общества XVIXVII веков, не может не бросаться в глаза: их можно встретить не только в многочисленных трактатах, но и в художественных произведениях (от Бургмейера до Брейгеля, Ständebücher) и храмовых росписях (Gnadentafel, Kapelle Altötting).

Как лечили меланхолию? K XVI веку в Европе возникла система госпиталей, в которых содержались и психически больные. ${ }^{26}$ Обращения с психически больными и с “бесноватыми” были во многом схожи между собой - травяные настои, пускание крови, вызов рвоты, охлаждение-нагревание, посадка на цепь, а также молитвы. ${ }^{27}$

Лазареты были частью церковной организации и состояли под руководством епископств, священников и монашеских орденов. Чаще всего, госпитали были при крупных монастырях. ${ }^{28}$ Быт в таких учреждениях находился под сильным влиянием религиозного расклада и структурно был очень схож с дисциплиной монашеского ордена. ${ }^{29}$ Религиозные истоки лечебных учреждений продолжили существование в эпоху Реформации. Многие упраздненные к XVIII веку монастыри, как протестантские, так и католические, стали использоваться как госпитали, сохранив при этом свой монастырский характер быта, и в эпоху Просвещения и во время Модерна. ${ }^{30}$ Западные исследователи только недавно обратили свое внимание на религиозный характер госпиталей. Между тем, связь религии с опекой о безумных позволяет по-новому интерпретировать развитие дискурса о сумасшествии от христианского средневековья к научному Модерну. ${ }^{31}$ Обращение с больными в госпиталях невозможно понять без фактора духовного импульса, исходившего от монахов. Для российских сюжетов эти вопросы также более чем актуальны.

Другим важным дискурсом меланхолии является связь практик ее исцеления с христианским воззрением о дисциплинирующей и исправляющей (лечащей) функции труда. Роберт Бертон выразил уверенность в “Анатомии меланхолии": "There is no greater cause of melancholy than idleness, no better cure than business." ${ }^{2}$ Так, в Англии в XVII веке безумные направлялись в исправительные дома ("house of correction"). Также как и нидерландские tuchthuizen, они являлись комбинированными институтами, где содержались душевнобольные, а также нищие и бродяги. ${ }^{33}$ В XVIII веке неприемлемое поведение и безумие были двумя сторонами одной медали и подлежали исправлению заключением и трудом. Так, в Саксонии, в исправительный дом Вальдхайм ссылались так называемые физические и “моральные” сироты, то есть те, которых считали недостаточно

\footnotetext{
${ }^{26}$ Watzka, Vom Hospital zum Krankenhaus, 41.

${ }^{27}$ Ibid., 17.

${ }^{28}$ Ibid., 59 .

${ }^{29}$ Ibid., 67.

${ }^{30}$ Christina Vanja, “Offene Fragen und Perspektiven der Hospitalgeschichte," in Europäisches Spitalwesen. Institutionelle Fürsorge in Mittelalter und Früher Neuzeit, eds. Martin Scheutz, Andrea Sommerlechner, Herwig Weigl \& Alfred Stefan (Vienna: Böhlau Verlag, 2008) 19-40, here 2.

${ }^{31}$ Ibid., 23.

${ }^{32}$ Robert Burton, Anatomy of Melancholy. цит. по Radden, The Nature of Melancholy, 17.

${ }^{33}$ Spierenburg, The Prison Experience.
} 
воспитанными в понятиях времени. Сюда же относились и rasende, tolle сумасбродные. ${ }^{34}$

Греховность меланхолии, ее связь с acedia, (смертным грехом уныния), дополнилась грехом "desidia“, (лени) и морализирующим постулатом Лютера "кто не работает тот не ест.”35 Труд представлялся в проповедях долгом перед Господом, а божья благодать - зависящей от исполнения трудового долга на земле. ${ }^{36}$ Бедность связывалась с ленью, со страданием, в котором повинен сам человек, с грехом. Исправительные дома соединяли в себе функцию богаделен, госпиталей, работных домов и домов смирения. Труд - прежде всего аскеза, лечение и наказание за грех.

Начиная с 1600 гг. меланхолия представляет в трудах медиков и писателей, а также в автобиографических свидетельствах современников, существенную литературную составляющую. Образы ее при этом совершенно различны. Категории безумства не были четко разграничены и часто употреблялись в разных значениях. В XVIII веке с “диагнозом” меланхолии в исправительные дома долгаузы - попадают люди разных сословий, часто по просьбе членов семьи. ${ }^{37}$ Меланхолия в таких случаях сопровождает безумное, непристойное поведение и поэтому является скорее моральной, чем медицинской проблемой (хотя и остается болезнью). В этом своем обличии она схожа с проблемой пьянства, когда буйствующий человек является обузой для своего окружения, но не может быть призван к ответственности из-за нахождения в неадекватном состоянии. Не удивительно, что из-за семантической связи меланхолии с пьянством меланхолия представлялась проблемой социальной безопасности.

В Россию меланхолия пришла в медицинско-патологическом дискурсе. Также как и на Западе, она стала одной из форм безумства, включавшей множество проявлений. Уже первые лекари, иностранные лекари в XVII веке, говорили о черной болезни, черной немощи и предлагали способы лечения. Здесь примечательно символическое единство в определении меланхолии: черная желчь и черная кручина, темное, подавленное самочувствие. Переводы латинских Травников Hortus Sanitatis (Kräuterbuch), определяли ее “черной кручиной от мокрости», хипохондрикой, в голове обмороком. ${ }^{38}$ В дальнейшем, мы увидим, какую роль играл (принудительный) труд в дискурсе об исправлении меланхолии в России, а также какая функция была у русских православных монастырей в лечении и опеке над безумными. Почти все перечисленные “западные” облики меланхолии встречаются нами и в России, - за исключением, пожалуй, т.н. “серой

\footnotetext{
${ }^{34}$ Falk Bretschneider, "Kinder und Jugend im Zuchthaus," in Hexenkinder - Kinderbanden - Straßenkinder, eds. Wolfgang Behringer \& Claudia, Opitz-Belakhal (Bielefeld: Verlag für Regionalgeschichte, 2016), 379380.

${ }^{35}$ См. об этом дискурсе подробное исследование Helmut Keipert, "Von Luther über Bebel zu Lenin und Stalin: Das russische 'geflügelte Wort' Кто не работает, тот не ест," (Kto ne rabotaet, tot ne est) Die Welt der Slawen. Internationale Halbjahresschrift für Slavistik 63 (2018): 215-242.

${ }^{36} \mathrm{O}$ развитии дискурса о труде в Европе раннего нового времени см. Falk Bretschneider, Gefangene Gesellschaft: Eine Geschichte der Einsperrung in Sachsen im 18. und 19. Jahrhundert (Konstanz: UVK, 2008). ${ }^{37}$ Bretschneider, Gefangene Gesellschaft, 130.

${ }^{38}$ От меланколия сиречь от мокрости и оть черной кручины. Травник Любч, 221, 17 век. (Травник Лечебник, перевод немчина Николая Любчанина (Булева), 1534, Рукоп. ГИМ, Увар. 387, (1), Царск. 615. 17 в. лат. Hortus Sanitatis (Strasburg 1490). Болезнь: хипохондрика именуемая и меланхолия, и в голове обморок. Мат. медиц., 1169. 1679. Словарь русского языка XI-XVII вв. Т.9. (Москва: Наука, 1982), 77. (Slovar' russkogo iazyka XI-XVII vv., T. 9 (Moscow: Nauka, 1982), 77).
} 
(гениальной) меланхолии” в аристотельском смысле, когда нарушение гуморов делает людей гениями в творчестве, политике, философии.

\section{Меланхолия как невменяемость и юридическая проблема}

Случай меланхолика Иллариона - один из первых в практике духовного суда Российской империи. Здесь можно увидеть, как медицинский дискурс начинает проникать в язык судебный. Суд начинает заниматься вопросом невменяемости безумных и правовыми основами для безопасности их самих и их окружения.

“Временную меланхолию," “диагностицировал” медик новгородского полка у попа Андрея в 1729 году. На попа доносил в Синод протопоп Федор: “поп Андрей много пьянствует и от такого пьянства впадает в меланхолию." 39 При осмотре и опросе оказалось, что Андрей десять лет назад был бит “злыми людьми смертным боем, и голову ему изрубили, от чего поп приходит в меленхолию, а пьянства де за ним не признаваеца." ${ }^{\circ}$ Андрея освободили от священнослужения, но дальнейших дисциплинарных санкций не последовало. Священник был признан невиновным, а его “меленхолия" - следствием внешнего воздействия на голову, т.е. на разум пострадавшего.

Медики, привлеченные к судебным процессам, могли своим освидетельствованием сохранить человеку жизнь, особенно, когда можно было доказать объективную причину появление меланхолии через внешнее воздействие, как избиение, пытки. В 1762 году, медик Гагеманн установил, что обвиняемый в богохульстве солдат Федор Хлазунов в Тайной канцелярии "при сечении батогами с ума сшедши.” Так Фёдор - вместо смертной казни -попал в Любятовский монастырь Псковской епархии, ${ }^{41}$ где о нем вскоре забыли и отпустили, как излечившегося, только через восемь лет. ${ }^{42}$

Эти случаи демонстрируют, что в судебных делах стали использоваться консультации с медицинскими авторитетами - практика, распространенная в Европе с XVI века. ${ }^{43}$ Здесь на судейские процессы начали влиять традиции римского права в отношении “безумных": наказание, применяемое к человеку, совершившего преступление в полном рассудке, не могло быть применено к безумцу. Безумец не может понять цели наказания (заключавшейся в исправлении) и поэтому к нему может быть предпринята только мера ограждения от общества в целях безопасности. ${ }^{44}$ В процессах над безумными преступниками в Европе XVI - XVII веков судьи часто сталкиваются с проблемой определения

\footnotetext{
${ }^{39}$ Центральный Государственный исторический Архив Санкт-Петербурга (ЦГИА СПб), Ф.19, оп. 1, д. 687, л.1. (Tsentral'nyi Gosudarstvennyi istoricheskii Arkhiv Sankt-Peterburga (TSGIA SPB), F.19, op. 1, d. 687, l.1.).

${ }^{40}$ ЦГИА СПб Ф. 19, оп. 1, д. 687, л.14 (TSGIA SPB F. 19, op. 1, d. 687, 1. 14).

${ }^{41}$ По ст. 1 Воинского Артикула (1715) за идолопоклонство, чернокнижье, (...) богохульство и суеверие предполагалась смертная казнь через сожжение. См. текст Воинского Артикула, дата обращения, Ноября 23, 2019, http://www.hist.msu.ru/ER/Etext/articul.htm.

42 Так, в 1762 году на солдат Федор Хлазунов был обвинен своими однополчанами в произнесении богохульных слов. Псковский епископ Иннокентий пишет в 1770 году в Синод, что Федор от болезни ума освободился. Вскоре Федор был вновь определен в Псковский батальон. РГИА, 796, оп.43, д. 177, л. 1. (RGIA, 796, оp. 43, d. 177, 1. 1).

${ }^{43}$ Midelfort, History of Madness, 182: "medical theories of melancholy mental disorder did not only affect medical treatment. By thinking of melancholy as a medical condition one could justify the consultation of medical authorities in legal matters, as began in the late 16th century."

${ }^{44}$ Ibid., 192
} 
безумия и его доказательства. Медицинская экспертиза и понятия melancolia, furor начинают играть существенную роль в судебных процессах и входят в юридический язык, определяя, совершено ли преступление намеренно, или в безумном припадке. Свидетельствование психического здоровья для обвиненных заканчивалось по-разному: некоторым наказание смягчали, а некоторых приговаривали к смертной казни. Однако о полном освобождении от наказания не могло быть и речи: безумные наказывались телесно, заключались в тюрьмы; при этом их содержание сопровождалось духовным общением и посещением литургий. Так, для женщины, убившей своих детей в меланхолическом припадке (1596, Саксония), предполагалось, что литургия может “помочь ей услышать слово Божье о ее проступке и привести ее от отчаяния к вере в божественном милосердии...." 45

Как и в Европе XVI - XVII веков, основная масса меланхоликов России XVIII века встречается нам в судебных актах светских и духовных учреждений и в частных доношениях с просьбами об определении члена семьи в монастырь за “бесчинства." Связь меланхолии и проступков не случайна. Вопросы умышленного преступления политического (связанного с царской честью или изменой), или религиозного характера (богохульства), стали волновать и чиновников российских судебных институтов: Сената, Синода, Юстиц-Коллегию, и самого императора. Сенатское освидетельствование умалишенных стало официальной практикой Сената с 1722 года. ${ }^{46}$ Также, Тайная канцелярия определяла безумство человека по очевидности бреда. ${ }^{47}$ Различные коллегии определяли, как безумных, людей, подверженных пьянству, определяя их, как и западноевропейские институты в категориях социальной опасности, исходящей от больных.

Логичным следствием становится трансфер понятия меланхолии в петровской России: это или черножелчная болезнь, приводящая к помутнению рассудка, или внешняя травма головы, имеющая такие же последствия. Как уже показали случаи попа Андрея и Федора Хлазунова, меланхолия появлялась как следствие определенных пыток, приведших к травме головы и “изумлению,” часто она “рождалась” в Тайной канцелярии. Отправной точкой болезни была голова, разум, страдающий от природной или внешней меланхолии.

В Артикуле Воинском (1715), уголовном кодексе, разработанном Петром для регулярной армии, в 19 главе, 164 артикуле мы впервые встречаем официальное употребления термина меланхолии:

Артикул 164. Ежели кто сам себя убьет, то надлежит палачу тело его в безчестное место отволочь и закопать, волоча прежде по улицам или обозу. Толкование. А ежели кто учинил в безпамятстве, болезни, в меленколии, то оное тело в особливом, но не в безчестном месте похоронить. И того ради должно, что пока такой самоубийца погребен будет, чтоб судьи наперед о обстоятельстве и притчинах подлинно уведомились, и чрез приговор определили б, каким образом его погребсти.

Меленхолия как диагноз, как медицинское понятие, стало секуляризированной версией одержимости, беснования. Но в отличии от ситуации, когда человек

\footnotetext{
${ }^{45}$ Ibid., $185-186$.

${ }^{46}$ Янгулова, Институционализация психиатрии в России, 42, 56. (Iangulova, Institutsionalizatsiia psikhiatrii $v$ Rossii, 42, 56).

${ }^{47}$ Там же, 130. (Tam zhe, 130).
} 
попадал под обаяние беса - и активно практиковал чернокнижье и колдовство, или мнил себя юродивым, меленхолик не был виноват в своем заболевании, т.е. был не в себе, совершая тот или иной проступок. С самоубийцы, совершившего грех в состоянии меланхолии, частично снималась вина за преступление заповедей.

Итак, использование термина меланхолия как обозначения болезни означало де-криминализацию преступления. В этом важное сходство с развитием понятия в Европе раннего нового времени, когда юристы начали заниматься вопросами воли и осознания преступления и тем, насколько преступники-меланхолики подлежат наказанию за преступления, совершенные в состоянии помрачения разума. ${ }^{48}$

В России XVIII века меланхолическое заболевание было не только результатом свидетельства судей Синода и Сената но и диагнозом, который ставили себе сами обвиняемые. Судьи должны были доказать помешательство ума или его "затмение,"49 т.е. определить, совершал ли обвиняемый преступление неосознанно, и, соответственно, является не в состоянии осмыслить и признать вину за содеянное. Многие документы свидетельствуют о том, что обвиняемые в преступлениях пытались смягчить приговор ставя себе диагноз меланхолии..5 Судебные и “исправительные” практики обращения с умалишенными в очередной раз предстают перед нами как не-система, типичная для переходной эпохи, - XVIII века.

В 1766 году служивший при гошпиталях в Риге премьер-майор Авраам Коверегин пытался объяснить (или оправдать) свое прелюбодеяние (итогом внебрачной связи майора были два незаконнорождённых младенца) перед духовным судом “меленхолической болезнью” его жены Ирины. Синод не усмотрел в Ирине меланхолии и наказал Коверигина покаянием за грехопадение..$^{51}$

В 1765 году дворянин Михаил Ратицов был приговорен Севской губернской канцелярией за сопротивление при попытке его ареста ${ }^{52}$, при котором он, отбиваясь, застрелил двух солдат, к “запятнанию” (лишению чести), телесному наказанию и ссылке в Сибирь в вечные труды. Императрица Екатерина Вторая усмотрела, однако, в случае Ратицова “некоторое в разуме повреждение” и велела смягчить наказание, на что Сенат предложил ей сослать Ратицова в монастырь

\footnotetext{
48 "Citing on Justinian's digest, 1.18. 13-14, the jurists acknowleged that an insanity defense of course existed." Midelfort, History of Madness, 183.

${ }^{49}$ Феномен "отсутствия ума" просматривается уже в актах XVII века. С. Шаляпин и А. Плотников, “Особенности заключения умалишенных преступников в России XVII-XVIII вв.," Вестник института. Преступление, наказание, исправление. 2 (42) (2018): 27-39, 31. (S. Shaliapin i A Plotnikov, "Osobennosti zakliucheniia umalishennykh prestupnikov v Rossii XVII-XVIII vv.").

$5^{50}$ В 1738 году осужденный за богохульство протопоп Екатеринбурга Иван Федосьев пытался избежать наказания, ссылаясь в Тайной Канцелярии на меланхолическую болезнь и пьянство. (Его, тем не менее, приговорили к смертной казни.) Купец Федор Четчуев, также, уповал на защитную силу “меланхолии." Он охарактеризовал пение в Воскресенском монастыре как “бесовское.” Оказавшись под следствием Тайной канцелярии, он смог доказать что находился в состоянии меланхолии. Его наказали более мягко - выпороли плетьми. Об этих случаях см. у Смилянской, Волшебники, богохульники, еретики, 211, 209. (Smilianskaia, Volshebniki, bogokhul'niki, eretiki, 211, 209).

${ }^{51}$ ЦГИА СПб. Ф.19., Оп.1., Д. 6595. 1767 год. (TSGIA SPB. F. 19, Op. 1, D. 6595.1767 god.).

$5^{2}$ Его пытались взять по жалобе его матери на неучтивость и “противности.” По ведению Сената об отсылке в монастырь Михаила Ратицова, РГИА, Ф. 796, оп. 47, д. 125. 1766 год. л.7, л.9. (RGIA, F. 796, op. 47 , d. 125.1766 god. 1. $7,1.9$ ).
} 
“дабы от него подобных сему неистовств и неповинным людям вреда впредь немогло произойти.” Содержать следовало его бы “скована, употреблять притом ко всяким монастырским работам, а ежели придет в чувство, то учинить ему сверх того церковное покаяние." ${ }_{33}$ Следуя предложению Сената и высочайшему согласию с ним императрицы, Синод отправил Ратицова в Соловецкий монастырь, приказав настоятелю монастыря Досифею приставить к нему определенный караул, “который водил бы его к всякому священнослужению к церкви и стоять ему там на паперти.”54 Следующие 19 лет регулярные репорты настоятелей в Синод о состоянии разума Ратицова повторяются слово в слово: он по прежнему пребывает в безумии. Двадцать лет Ратицов жил в монастыре и не был переведен ни в Спасо-Евфимиев монастырь, используемый в качестве места содержания изумленных, ни в Дом призрения, учрежденный в России уже в 1775 году.

Говоря о судебных практиках, стоит напомнить о специфическом характере российского светского и церковного права в XVIII веке. Многие исследователи отмечают наслоение светской и церковной сферы в русском праве начиная с древнего времени. ${ }^{55}$ Действительно, развитие права, юстиции, пенитенциарных практик, невозможно понять без рассмотрения церковного права, церковного языка и практик церковного наказания. Обе области права связаны друг с другом, светские и церковные акторы находятся между собой в процессе коммуникации и переговоров. Церковь ни в коем случае не является “служанкой государства" 56 перспектива, до сих пор распространенная в исследованиях на тему монастырской ссылки. ${ }^{57}$ Похожие дифференцированные подходы по отношению к истории власти и церкви выбрали А. Лавров ${ }^{58}$ и Е. Смилянская, ${ }^{59}$ описывая сложные и противоречивые отношения между властью и государством в преследовании колдовства. Новые исследования показали, что судебные и пенитенциарные практики беспорядочны, ситуативны, а отношения между клириками и бюрократией осложнены желанием светской власти доминировать и необходимостью в легитимации за счет сильной религиозной традиции и церковной символики. Поэтому так важно рассмотреть специфику ссылки изумленных в монастыри в XVIII веке.

\section{Меланхолия и монастырь: религиозные традиции обращения с безумством и новый курс Gute Policey}

\footnotetext{
53 По ведению Сената об отсылке в монастырь Михаила Ратицова, РГИА, Ф. 796, оп. 47, д. 125.1766 год. л.7, л.9. (RGIA, F. 196, op. 47, d. 125. 1766 god. 1. 7, 1. 9).

54 Там же, л. 14. (Tam zhe, 1. 1).

${ }^{55}$ Stefan Plaggenborg, Pravda: Gerechtigkeit, Herrschaft und sakrale Ordnung in Altrussland (Paderborn: Verlag Wilhelm Fink, 2018), 215.

${ }^{5}$ Против этого тезиса достаточно аргументов у Gregory L. Freeze, “The Wages of Sin: The Decline of Public Penance in Imperial Russia," in Seeking God: The Recovery of Religious Identity in Orthodox Russia, Ukraine, and Georgia, ed. Stephen K. Batalden. (DeKalb: Northern Illinois University Press, 1993), 53-82.

57 См., например, Александр Павлушков, Карательно-исправительная система Русской православной церкви в имперский период (Вологда: ВИПЭ ФСИН России, 2014). (Aleksandr Pavlushkov, Karatel'no-ispravitel'naia sistema Russkoi pravoslavnoi tserkvi v imperskii period (Vologda: VIPE FSIN Rossii, 2014).

${ }^{8}$ А. С. Лавров, Колдовство и религия в России 170о-1740 (Москва: Древлехранилище, 20оо). (А. S. Lavrov, Koldovstvo i religiia v Rossii 1700-1740 (Moscow: Drevlekhranilishche, 2000).

${ }^{59}$ Смилянская, Волшебники, богохульники, еретики. (Smilianskaia, Volshebniki, bogokhul'niki, eretiki).
} 
Связь меланхолии с монастырской ссылкой имеет два объяснения: во-первых, религиозный контекст обращения с “бесноватыми” и, во-вторых, использование монастырей как мест заключения в разнообразных целях. До XVIII века душевные болезни в России, как и в Европе, рассматривались в рамках христианской религиозной культуры, ${ }^{60}$ т.е. о безумности и обращения с ней решали церковные иерархи. Церкви традиционно несли заботу об увечных, в том числе и о больных. Определение Феодосия (XI век) может служить примером взгляда духовенства на “бесноватых": “Бешеный страждет неволею и добудет вечной жизни, а пьяный волею страждет и добудет вечной муки. Ибо иерей придет к беснующимуса, сотворить молитву и прогонит беса, а над пьяным, если б сошлись попы со всей земли и молитву сотворили, то и тем не прогнали бы самовольного беса пьянства." помешанных: ни в уставе Владимира, ни в Кормчей.

Утилитарное использование монастырей светской властью было новой тенденцией. ${ }^{62}$ Эта практика началась уже в XVII веке, когда монастыри стали все чаще исполнять волю царя. ${ }^{63}$ Сумасброды-преступники ссылались в монастыри по царскому или по Патриаршему указу и освобождались, также, по указу. ${ }^{6}$ Тем не менее, это явление оставалось точечным. B XVIII веке меланхолики попадали в монастыри потому, как монастыри стали широко использоваться как места заключения (а с середины XVIII века и исправления) преступников. ${ }^{65}$ Таким

6о Янгулова, Институционализация психиатрии в Poсcuи, 20. (Iangulova, Institutsionalizatsiia
psikhiatrii v Rossii, 2о).
61 Сочинения препод. Феодосия, изд. Макарьевым в Ученых Записках Второго Отделения Императорской Академии Наук, кн.2, вып.2, стр. 197-198. Цитировано по: А. Шульц, “Призрение помешанных в России," Архив Судебной медицины и общественной гигиены, кн.1, ч.1 (1865), 3-4. (A. Shul'tz, "Prizrenie pomeshannykh v Rossii," Arkhiv Sudebnoi meditsiny i obshchestvennoi gigieny, kn. 1, ch. 1 (1865), 3-4).

${ }^{62}$ Сюда входит ссылка отставных солдат на пропитание в монастыри (начало этому было положено уже при Федоре Алексеевиче, отправлявшем отставных стрельцов в монастырские обители), использование монастырей как сиротских домов, богаделен, госпиталей и пр.

63 “Царь Михаил Федорович лета 7148 (?) ноября в 29 день ... указал послать в Кириллов монастырь под начало для того, что Микита Уваров в уме помешался.” цит. по Н. Н. Баженов, История московскаго доллгауза (Москва: Издание Московскаго Городского Общественнаго Упраления, 1909), 18. (N. N. Bazhenov, Istoriia moskovskago dollgauza (Moscow: Izdanie Moskovskago Gorodskogo Obshchestvennago Upravleniia, 1909), 18). О ссылке умалишенных в монастыри в XVII веке см. Шаляпин и Плотников, Особенности заключения умалишенных преступников в России. (Shaliapin i Plotnikov, Osobennosti zakliucheniia umalishennykh prestupnikov v Rossii).

${ }^{64}$ Царская грамота: Отдел письменных источников Государственного Исторического Музея (ОПИ ГИМ), Ф. 484, ед. 68, 1664 год. (Otdel pis'mennykh istochnikov Gosudarstvennogo Istoricheskogo Muzeia (OPI GIM), F. 484, ed. 68, 1664 god.): Отписка в монастырский приказ властей Кириллова монастыря о присланном “под начал” суздальце Семене Данилове Ярышкине, находившемся во исступлении ума. Указ патриарха: ОПИ ГИМ ф. 484, ед. 65, 1696 год (OPI GIM, F. 484, ed. 65, 1696 god.). От Патриарха Адриана архимандриту Кирилло-Белозерского Монастыря. Посланного старца Симоне за буйные поступки держать сначала в пекарне а селе не исправиться в крепости, в трудах, не давать ему чернил и бумаги и никого к нему не пускать. (Было показано, что Старец Симеон “браница”). См. также Шаляпин и Плотников, Особенности заключения умалишенных преступников в России. (Shaliapin i Plotnikov, Osobennosti zakliucheniia umalishennykh prestupnikov v Rossii).

${ }_{5}$ Об использовании монастырей в государственной системе наказаний см. С. О. Шаляпин, Церковно-пенитенциарная система в России XV-XVIII веков (Архангельск: ИПЦ САФУ, 2013); А. Павлушков, Карательно-исправительная система Русской православной церкви в имперский период (Вологда: ВИПЭ ФСИН России, 2014). (S. O. Shaliapin, Tserkovno-penitentsiarnaia sistema v 
образом, хотя изумленные и были судимы в том числе и светской властью, монастыри оставались местами ссылки и определяли практики “исправления." Показательно, что в первом проекте свода законов Российской Империи о преступлениях и наказаниях за них "Уложение российского государства, Книга 3, О злодействах какие штрафы и наказания последуют," начатой в 1721 году, ссылка в монастырь под начал назначалась в качестве санкции лишь в одном случае: бесчинного поведения в церкви и доказательства нахождения при этом в “исступлении ума."”6

Что означало под начал? Корни этого явления уходят в раннехристианские времена, когда заключение в монастырь назначалось как наказание для клириков (carcer). B VI веке во франконских королевствах эта практика была распространена и на светских людей. ${ }^{67}$ Православная церковь также подразумевала заключение в монастыре как религиозное дисциплинирование оступившихся монахов и монахинь. $^{68}$ Согрешивший клирик находился при этом под руководством опытного, “доброжительного” старца, с которым он вел беседы о своем грехе и таким образом исправлялся. Документы XVIII века свидетельствуют о том, что в монастырское подначальство для светских людей стало распространенной практикой.

В практике монастырского заключения раннего XVIII века подначальство для сумасбродов означало содержание их в изоляции, часто в железах или в отдельных карцерах, “дабы другим увечий не было.” Режим под начал превратился в жесткое смирение без религиозных занятий. Так, мужчины и женщины содержались “в особливой келье,” в ручных и ножных кандалах. В большинстве случаев караул сопровождал их в церковь к божественному пению, ${ }^{69}$ некоторых из них использовали в монастырских трудах. Таким образом, ссыльные изумленные часто содержались в карцерах, как и прочие преступники. Монастырь стал комбинированной институцией: оставаясь действующей обителью, он объединил в себе функции тюрьмы, богадельни, госпиталя и долгауза. Этим он схож с

Rossii XV-XVIII vekov (Arkhangel'sk: IPTs SAFU, 2013); A. Pavlushkov, Karatel'no-ispravitel'naia Sistema Russkoi pravoslavnoi tserkvi v imperskii period (Vologda: VIPE FSIN Rossii, 2014)).

${ }^{66}$ Российский Государственный Архив Древних Актов (РГАДА), Ф. 342, оп. 1, д. 33, ч.3, л.16. (Rossiiskii Gosudarstvennyi Arkhiv Drevnikh Aktov (RGADA), F. 342, op. 1, d. 33, ch. 3, 1. 16). В поздней версии было исправлено на “отсылать в правительственный Синод." Т.е. опять суть определения меланхолии связывается с преступлением против веры, с богохульством. Здесь следует повториться, что ни в каких других случаях ссылка в монастырь не являлась санкцией в действующем законодательстве XVIII века - ни в Уложении, ни в Артикулах, ни в других царских указах, хотя на практике использовалась достаточно широко.

${ }^{67}$ Julia Hilner, "Gregory the Great's 'Prisons': Monastic Imprisonment in Early Byzantine Italy," Journal of Early Christian Studies, 19:3 (2011): 433-471; W. Jezierski, "Monasterium panopticum," Frühmittelalterliche Studien 40:1 (2009): 167-182; Isabelle Heullant-Donat, Julie Claustre \& Elisabeth Lusset, Enfermements: Le cloître et la prison (VIe-XVIIIe siècle). (Paris: Publications de la Sorbonne, 2011).

68 Подробнее: Шаляпин, Церковно-пенитенциарная система России, 91. (Shaliapin, Tserkovnopenitentsiarnaia sistema Rossii, 91).

69 Это касалось как мужчин, так и женщин. Указ Троице Сергиева монастыря архимандрита Варлаама игуменье старице Латышевой по его императорского величества указу велено прислать из московской полицейской канцелярии безумную жену которая взята ... нагая (....) содержать ее в особливой келье в ручных и ножных железных оковах, а во время церковного богослужения к слушанию божественного пения для исправления ума приводить в церковь. РГАДА, Ф. 1441, оп. 1, д. 10, 1729 год. (RGADA, F. 1441, op. 1, d. 10, 1729 god.). 
комбинированными институтами Запада, соединяющими госпиталь, тюрьму и дом приюта. ${ }^{70}$

Петр I не только начал относится к проблеме слабоумия со вниманием (см. закон о “дураках" 1723 года $\left.{ }^{71}\right)$ и активно использовать монастыри как учреждения социальной помощи увечным и престарелым. Его указ 1723 года об использовании монастырей как мест для обеспечения старых и больных, расширил новое употребление монастырей для государственных нужд: ${ }^{72}$

Отставных драгунов, солдат престарелых, увечных и раненных, которые пропитания не имеют, отсылать в монастыри (...) Беснующегося отослать в монастырь и впредь таких отсылать в Священный Синод для определения в монастыри, а в монастырях держать их в особом месте, имея над ними надзирание, чтоб они не учинили какова себе повреждения и довольствовать их как в помянутом указе изображено. ${ }^{73}$

Фактически, указ Петра лишь закрепил законодательно уже существующую практику, только теперь изумленные были приравнены к больным солдатам, неспособным найти себе пропитание. В мышлении и действиях политических элит можно встретить удивительные пересечения попечения и полицейского порядка, благотворительности и контроля.

Рациональный, прагматический подход к монастырям и монастырской жизни отличал политику первого императора России. В этом его поддерживал Феофан Прокопович, вместе с которым он составлял Объявление о монашестве. Польза, благочиние и труд - главный предмет внимания Феофана: “Особливо же о должном монашеству трудолюбии все мои речи." ${ }^{4}$ Так, он предложил “старцев по монастырям убавить, а вместо того положить с монастырей пропитание на

70 Литература о западных многофункциональных учреждениях достаточно обширна. См., например, Natalia Muchnik, Les prisons de la foi: L'enfermement des minorités (XVI'-XVIII siècle) (Paris: Presses Universitaires de France, 2019); Bretschneider, Gefangene Gesellschaft; Spierenburg, The Prison Experience; Hannes Stekl, Österreichs Zucht- und Arbeitshäuser 1671-1920. Institutionen zwischen Fürsorge und Strafvollzug (Vienna: Böhlau Verlag, 1978); H. Steinert, Hubert Treiber, Die Fabrikation des zuverlässigen Menschen. Über die "Wahlverwandtschaft" von Kloster- und Fabrikdisziplin (Munich: Moos, 1980).

${ }^{71}$ Здесь он указал свидетельствовать Сенатом тех, кто „ни в службу, ни в науку не годятся, и если окажется дураком, то женитъся не допускать и деревень в наследство не справливать.“ Так правительство защищало имущество от разорения.

${ }^{72}$ О государственных мерах по контролю и попечению о бедных см., Н. В. Козлова, Люди дряхлые, больные, убогие в Москве ХVIII века (Москва: РОССПЭН, 2010) (N. V. Koslova, Liudi driakhlye, bol'nye, ubogie v Moskve XVIII veka (Moscow: ROSSPEN, 2010); М. Лавринович, "Столичные нищие и формы социального контроля в России 18 века," (M. Lavrinovich, "Stolichnye nishchie i formy sotsial'nogo kontrolia v Rossii 18 veka,") in Eighteenth-Century Russia: Society, Culture, Economy, eds. Roger Bartlett \& Gabriela Lehmann-Carli (Berlin: Lit Verlag, 2007), 403-416.

${ }^{73}$ Цитировано в документе о принятии безумного Гавриила Иванова, РГИА, ф. 796, оп. 54, д. 297, 1767 год. л. 1 об.-2. (RGIA, f. 796, op. 54, d. 297, 1767 god, l. 1 ob.-2). В 1735 году этот указ был подтвержден: "по силе означенных Именных 1727 и 1735 г указов повелено было от Синода посылающихся из тайной канцелярии престарелых и в уме поврежденных колодников для исправления принимать в монастыри по прежнему (...) а тайной канцелярии оных колодников (...) отсылать в коллегию экономии, которой, принимая оных отсылать прямо в те монастыри, кто в какой назначен будет, и довольствовать из оставшимися монастырскими порциями и караул к ним определить из тех же солдат, которые на пропитании при монастырях обретаются."

${ }^{74}$ И. Чистович, Феофан Прокопович и его время. (Санкт-Петербург: Тип. Имп. академии наук, 1868), 140. (I. Chistovich, Feofan Prokopovich i ego vremia (St. Petersburg: Tip. Imp akademii nauk, 1868), 140). 
больных и раненых солдат и драгун."75 Прокопович был первым, кто предложил создать первый “профильный” монастырь для сумасбродов: Александро-Свирский монастырь - где “изумленные,” 15-20 человек, должны были находится под надсмотром врача. ${ }^{76}$

Синод сопротивлялся использованию обителей для содержания сумасбродов. Интересно, что члены Синода аргументировали именно медицинским дискурсом, рассматривая изумление уже не столько действием беса и злых духов, сколько медицинским знанием. Так, в 1725 году последовало определение Синода об отсылке изумленных (солдат) в гофшпиталь лечебную, где “надлежит в болезни обретающихся докторам осмотреть и лечить, понеже знатно, что б них болезнь обретается, которая может и исцелиться. Ежели уже по докторскому свидетельству всесовершенно та болезнь неисцелима... и покажется то беснование от злых духов, то для исправления духовного под синодальное ведомство они и примутся. А без такого свидетельства в монастыри отсылать не надлежит."77 Синодальный канцелярист Тишин отказывался принимать безумных без свидетельства. Они должны были сначала быть осмотрены, освидетельствованы в гофшпиталях..$^{78}$ Примечательно, что церковь все еще признавала возможность того, что изумление может быть вызвано действием злых духов, но предлагала медицинское освидетельствование и лечение вместо безотчетной отсылки в монастыри.

В 1726 году Военная коллегия по указу Екатерины I. приказала сумасбродных солдат, содержащихся в Санкт Петербургском госпитале:

содержать в особых чюланах и когда случится при госпитале работа, тогда посылать их на тоё работу, скованных в цепях и смотреть за ними накрепко, чтоб они и над собою и над другими какого дурна не учинили (...) Буде же они от того содержания и прилежного лечения в надлежащее состояние не придут и, по докторскому свидетельству, явится та болезнь неисцелима или покажется (Как Синод рассуждает) то их изумление от злых духов, тогда кригс коммисариату доносить о том военной коллегии, но понеже беснующихся, для исправления духовного, велено отсылать в Синод. ${ }^{79}$

Реальностью же было то, что госпитали часто отказывались принимать душевнобольных и они все равно оказывались в монастырях. ${ }^{80}$ Сенат и

\footnotetext{
75 Там же. (Tam zhe).

${ }^{76}$ См. также Шаляпин, Плотников, Особенности заключения умалишенных преступников, 37. (Shaliapin, Plotnikov, Osobennosti zakliucheniia umalishennykh prestupnikov, 37).

${ }_{77}$ РГИА. ф. 769, оп. 25, д. 448. (RGIA. F. 769, ор. 25, d. 448).

${ }^{8}$ Описание документов и дел, хранящихся в архиве Святейшего правительствующего синода (ОДДС), 1725 год, т.5, номер 135. (Opisanie dokumentov i del, khraniashchikhsia v arkhive Sviateishego pravitel'stvushchego sinoda (ODDS), 1725 god, t. 5, nomer 135).

79 “Содержание умалишенных при Екатерине первой,” Русский Архив, кн.2 (1876), 36о. (“Soderzhanie umalishennykh pri Ekaterine pervoi,” Russkii Arkhiv, kn. 2 (1876), 36o).

${ }^{80}$ ОДДС, т. 11, стб. 283 (так же РГИА ф. 796, оп. 12, д. 212), 14.6.1731 - 26.1. 1741. (ODDS, t. 11, stb. 283 (tak zhe RGIA f. 796, op. 12, d. 212), 14.6.1731 - 26.1.1741). В 1731 году Архимандрит Новоспасского монастыря Феофил предлагал поместить изумленных иноземцев - колодников Адама Кубе и Матиаса Хрестьяна Кроля, размещенных в его монастыре для лечения, в госпиталь. 15 декабря Синод изъявил согласие на предложение архимандрита. Однако из московской гофшпитали получено было доношение, что означенные иноземцы уже раньше были на излечении и надежды на
} 
правительство игнорировали протесты Синода и продолжили ссылку в монастыри умалишенных. Нельзя говорить о том, что монастыри были госпиталями: как уже говорилось, здесь практиковалось подначальство в форме изоляции и смирения. Изумленные часто, как и другие заключенные, забывались и продолжали содержаться в монастырях уже будучи в полном уме.

Итак, до 176о-х гг законодательство об изумленных ограничилось определением их к отсылке в монастыри. ${ }^{81}$

Ситуация начала меняться во время короткого правления Петра Третьего. В указе 1762 года он велел “безумных, ежели родственники иметь оных у себя не пожелают, не в монастыри их определять, но построить на то нарочный дом, каков то обыкновенно и в иностранных государствах учреждены доллгаузы....”

Практически сразу Сенат обратился в Академию Наук с запросом об опыте иностранных государств. В 1765 году Академией за границу был послан историк Август Шлецер с целью осмотреть долгаузы и составить о них отчет. ${ }^{82}$ Академик Г. Ф. Мюллер предложил проект "О учреждении дома для безумных (Dollhaus)":

построить для них особое строение каменное о двух или трех этажах с небольшой церковью, для помещения на первом этаже бешенных, на втором меланхоликов и лунатиков, на третьем эпилептиков. Меланхолики и лунатики держатся по мере их болезней. Некоторые могут жить по два и по три человека в камере и за общим столом кушать. Доктор пользует их и многие выздоравливают, священникам ходить и испытывать, которые из них в состоянии понимать их учение, и с усердием Бога молить. ${ }^{83}$

В этом нереализованном предложении мы впервые видим попытку понятийного разграничения меланхоликов от других форм помешательства, по крайней мере, что касается их распределения на этажах долгауза...

\section{Меланхолия как беспомощность: Дома призрения как результат Екатерининского Просвещения?}

После указа Петра III об учреждении долгаузов возник вопрос, что делать с изумленными пока они строятся. Было решено назначить специальные монастыри: Синод уже в 1762 году отвел для этих целей в Москве Андреевский

исправление их в уме нет, а держать их в городской гофшпитали невозможно, понеже упрямством, непотребствами и криком чинят другим больным беспокойство. Доктор Бидлоо просил не присылать тех иноземцев. Они остались в Новоспасском монастыре.

${ }^{81}$ Право Тайной канцелярии ссылки умалишенных в монастыри было подтверждено указами Анны Иоанновны в 1735 и 1738 годах. Подробнее: С. Шаляпин, “Умалишенные преступники в монастырском заточении XVIII века,” в Религийный чиник в истории права, держави та юридичной думки (Киев: Грінь Д. С, 2016), 247-254; С. Смагина, “Переписка Сената, Синода Тайной канцелярии о призрении сумасшедших в XVIII веке,” Печать и слово Санкт Петербурга, Ч. 1 (Санкт-Петербург: СПГУТД, 2013), 201-208. (S. Shaliapin, "Umalishennye prestupniki v monastyrskom zatochenii XVIII veka,” v Religiinyi chinik v istorii prava, derzavi ta iurudichnoi dumki (Kiev: Grin’ D. S, 2016), 247-254; S. Smagina, "Perepiska Senata, Sinoda Tainoi kantseliarii o prizrenii sumasshedshikh v XVIII veke," Pechat' i slovo Sankt Peterburga, Ch. 1 (St. Petersburg: SPGUTD, 2013), 201-208).

${ }^{82}$ Из протоколов Академии Наук, цит. по Шульц, Призрение помешанных в России, 7. (Shul'ts, Prizrenie pomeshannykh $v$ Rossii, 7).

${ }^{83}$ Баженов, История московского доллгауза, 27. (Bazhenov, Istoriia moskovskogo dollgauza, 27). 
монастырь, а в Новгородской епархии Зеленецкий. Тем не менее, на практике, как мы уже видели на примере Михаила Ратицова, ссылка в прежние монастыри продолжилась и далее. Еще один пример: в 1768 году, прапорщик в отставке Никифор Ростовцев, осужденный за убийство своего крестьянина, был признан страдающим от "меланхолической болезни” и приговорен к отсылке в монастырь “для исправления в уме на кошт колодника и под присмотр его людей." 4

Особенным местом для заключения безумцев стал Спасо-Евфимиев монастырь в Суздале. 6 ноября 1766 года, Екатерина II указала перевести тех, кто был сослан для исправления в уме по монастырям московской епархии “для лучшего за ними присмотра и сохранения жизни, равно чтобы в них какого по безумию их вреда учинено не было в Суздальской епархии Спасо-Евфимиев монастырь." ${ }^{5}$ Примечательна новизна целеполагания, которое императрица сформулировала для настоятеля монастыря: “чтобы он со своей стороны употреблял в содержании колодников в исправлении их в уме возможные старания." ${ }^{86}$ Это повеление передал Синоду князь Александр Вяземский, он же и был активным поборником и может быть, даже автором этой идеи. ${ }^{87}$ В приказе говорилось и о режиме содержания буйных: “Содержать оных безумных в отведённых архимандритом порозжих двух или трёх покоях, однако не скованых кои же смирны и сумазбродства не делают. Таких пускать для слушания Божественнаго пения в церковь, Буде ж из сих безумных которой в уме исправится, то архимандриту освидетельствовать самому." 88 (потом должен был свидетельствовать воевода, прим. автора).

В 1776 Вяземский руководил осмотром безумных колодников в СпасоЕвфимиеве монастыре, “есть ли за ними желаемое человеколюбивое христианское призрение.” 89 По осмотру оказалось, что содержащиеся в монастыре изумленные (27 человек) - самых разных сословий, возраста и происхождения. Здесь и титулярный советник, и шкипер, и крестьянин, один француз, не говорящий порусски, один немец, архимандрит, поп, студент и купец. Монастырь служил местом ссылки для всех слоев общества.

По результатам отчета из монастыря, выявившим много недостатков, губернатор Москвы Волконский приказал разделить сумасбродных от спокойных, не наказывать сумасбродов палками, а “держась человеколюбия...” То Также, за то, что прежний архимандрит не особо утруждал себя исправлением колодников, он был переведен в Можайский Лужицкой монастырь. Новизна режима в Суздальском монастыре состояла в том, что к работе сосланных не принуждали. Монастырский труд как исправление сохранился лишь для криминальных или бытовых преступников. Быт узников состоял из посещения церковных служб и скромного пропитания.

\footnotetext{
${ }^{84}$ ОДДС Т. 50, н. 61 (18.2.1770), стб. 77. (ODDS T. 50, n. 61 (18.2.1770), stb. 77).

85 “... ибо чрез то он может себя оказать по званию своему и сохранению жизни человеческой полезным”. Инструкция Екатерины РГИА Ф. 796, оп. 47, д. 355 (6.11.1766). (Instruktsiia Ekateriny RGIA f. 796 , ор. 47 , d. 355 (6.11.1766).

86 Там же. (Tam zhe).

${ }^{87}$ В 1766 году Вяземский, генерал-прокурор Сената, по личному указу ссылает Емельяна Титова в Спасо-Евфимиев монастырь. РГАДА, ф.7, оп.1, д. 2246. (RGADA, f. 7, op. 1, d. 2246). Титов прожил там до 1800 года.

${ }_{88}$ РГИА ф. 796, оп.47, д.355. 1766, л. 3-4. (RGIA f. 796, ор. 47, d. 355. 1766, 1. 3-4).

${ }^{89}$ РГАДА, ф.7, оп.2, д.2494, л.1об. (RGADA, f. 7, op. 2, d. 2494, l.10b).

$9^{\circ}$ Там же, л.27. (Tam zhe, 1. 27).
} 
Официально использование монастырей как мест отсылки душевно больных должно было прекратиться с изданием положения о Приказах Общественного Призрения, ${ }^{91}$ принятого 7 ноября 1775 в акте реформы местного управления “Учреждения для управления губерний Всероссийской империи." Статья 389 впервые разделила по функциям комбинированные учреждения: под надзором Приказов находились работные дома (для неимущих), богадельни, больницы и дома для сумасшедших, смирительные дома (последние особенно - для “общаго благочиния и спокойствия семей.") Для заботы о сумасшедших предписывалось следующее:

...приказу общественнаго призрения надлежит иметь попечение, чтоб дом избран был довольно пространный и кругом крепкий, чтоб утечки из него учинить не можно было. Токовый дом снабдить нужно пристойным, добросердечным, твердым и исправным надзирателем и нужным числом людей для смотрения, услужения и прокормления с ума сшедших, к чему нанимать можно или из отставных солдат добрых и исправных, или же иных людей за добровольную плату, кои бы обходились с ума сшедшими человеколюбиво, но при том имели за ними крепкое и не ослабное во всякое время смотрение, чтоб с ума сшедший сам себе и ни кому вреда не учинил; и для того держать с ума сшедших по состоянию с ума сшествия, или каждого особо заперта, или же в таком месте, где от него ни опасности, ни вреда учиниться не может, и приложить старание о их излечении. ${ }^{92}$

Уже спустя год после издания Учреждения в 1776 году в Новгороде был устроен первый дом для изумленных, а в 1777 году в Москве вместе с Екатерининской больницей открываются и инвалидный дом, богадельня, рабочий и смирительные дома. ${ }^{93}$ Формы церковной опеки над душевно больными должны были быть вытеснены медицинским и социальным призрением, и, в случае “смирительных домов” - рациональной трудотерапией. Однако, как мы видим на примере рапорта Вяземского из Спасо-Евфимиева монастыря, переводить заключавшихся там безумцев в специальные больницы никто не торопился.

Екатерининское законодательство должно было упорядочить обращение с безумными преступниками. В указе “Учреждения...” 1775 года, в ст. 399, было определено, что преступления, “учиненные безумным, или малолетним, и дела колдунов и колдовства, по елику в оных заключается глупость, обман и невежество, отсылать в совестный суд, который един право имеет учинить о вышеписанном решение." ${ }^{4}$ Совестному суду вверялось “осторожное и

\footnotetext{
${ }^{91}$ И. В. Константиновский, Русское законодательство об умалишенных, его история и сравнение с иностранными законодательствами (Санкт-Петербург: Тип. М. М. Стасюлевича, 1887), 27. (I. V. Konstantinovskii, Russkoe zakonodatel'stvo ob umalishennykh, ego istoriia i sravnenie s inostrannymi zakonodatel'stvami (St. Petersburg: Tip. M. M. Stasiulevicha, 1887, 27).

92 Учреждение, дата обращения, Ноября 23, 2019, https://constitution.garant.ru/history/act16oo1918/2350/. (Uchrezhdenie, data obrashcheniia, November 23, 2019, https://constitution.garant.ru/history/act160o-1918/2350/).

${ }_{93}$ Баженов, История московского доллгауза, 30-31. (Bazhenov, Istoriia moskovskogo dollgauza, 30-31).

94 Учреждение, “Дела касающияся до таковых преступников,” 399, дата обращения, Ноября 23, 2019, https://constitution.garant.ru/history/act160o-1918/2350/. (Uchrezhdenie, "Dela kasaiushchiiasia do
} 
милосердное окончание дел ему порученных," 95 суд мог определять состояние обвиняемого безумного и меру его наказания. Как упомянуто ранее, Указ “Учреждения...” определял констатацию факта “с ума сшествия” поводом для определения в Приказы Общественного Призрения. Значение этого шага в просвещенческой политике Екатерины II сложно переоценить: гражданский суд должен взять на себя дело определения и опеки над безумными, что означало конец религиозной составляющей дискурса о безумии. Тем не менее, то, по каким критериям суд должен был определять вменяемость преступника, оставалось неясным, что открывало дорогу подкупу. Яркой иллюстрацией этому может служить пример “меланхолика” Ярославской губернии - отставного капитана Федора Бакунина.

Его дело прогремело в 1778 году в Рыбинске: он забил Аксинью, свою крестьянку, поленом до смерти. После совершения злодейства, Бакунин пытался заставить своих крестьян захоронить ее тайно, но тело было найдено местным Земским судом. Бакунин придумал заявить себя человеком больным, страдающим “меланхолией." 96 В Рыбинском уездном суде он пытался оправдаться тем, что совершал преступления “в беспамятстве.” Свидетели - соседние дворяне, офицеры, священник засвидетельствовали под присягой, что Бакунин часто бывал в сумасшествии, хотя его караульные в Ярославском Правлении, где он был под арестом во время следствия, отзывались о нем как о человеке здоровом. Тем не менее, Ярославский Совестный суд не признал убийство, как умышленное, и решил, что Бакунин не заслуживает "наказания, подлежащего смертоубийцам." Суд постановил поместить Бакунина в “дом сумасшедших, где содержать его под присмотром." 97 Генерал-губернатор А. П. Мельгунов, однако, высказал Сенату свою уверенность, что Бакунин неправильно признан меланхолическим больным. Так как в Ярославле еще не были построены сумасшедшие дома, то его поместили на гауптвахте. Караульные, приставленные к помещику, вместо того, чтобы, как полагается в инструкции, не давать ему хмельного, “пьянствовали с помещиком."98 Кроме того, охранники регулярно рапортовали, что безумия за Бакуниным не примечается. Через некоторое время члены Приказа Общественного Призрения решились сами испытать, точно ли здоров Бакунин и нашли его в полном здравии. Дело отошло Сенату, а Мельгунов приказал Ярославскому коменданту освидетельствовать арестанта - теперь вместе с городовым лекарем. Мы не знаем, что показал лекарь, но комендант продолжал уверять Сенат в умственном расстройстве помещика: “Меланхолическая болезнь ныне час от часу в нем возрастает и никакой надежды к совершенному выздоровлению не подает."99 В 1780 году Сенат на имя Мельгунова дал знать, что Бакунина следует содержать в доме сумасшедших, куда он и был помещен. По прошествии тридцати лет он был освобожден по ходатайству генерал губернатора Новгородского, Тверского и ярославского Г. Ольденбургского самим императором Александром Первым.

\footnotetext{
takovykh prestupnikov," 399, data obrashcheniia, November 23, 2019, https://constitution.garant.ru/history/act1600-1918/2350/).

95 Учреждение, 397, дата обращения, Ноября 23, 2019, https://constitution.garant.ru/history/act16001918/2350/. (Uchrezdenie, 397, data obrashcheniia, November 23, 2019, https://constitution.garant.ru/history/act1600-1918/2350/).

96 “Меланхолик," Русский архив, т.11 (1876): 328-334. (“Melankholik," Russkii arkhiv, t. 11 (1876): 328-334).

${ }^{97}$ Там же, 332. (Tam zhe, 332).

${ }^{98}$ Там же. (Tam zhe).

${ }^{99}$ Там же, 333. (Tam zhe, 333).
} 


\section{Начало пути в монастырь: Меланхолия и семейные конфликты}

Преступление норм по причине безумия было во внимании не только властей, но и подданных. В описанных случаях достаточно часто встречается факт жалобы родственников на членов семьи и просьбы о заключении за "непотребное поведение.” Желание защитить честь, материальное благополучие или здоровье, прописанное в доношениях, удовлетворялось властями. Подданные всех социальных категорий - от дворян до крестьян - использовали практику доношений для решения семейных проблем. В доносах встречается и “меленколия" - как диагноз по отношению к себе, так и к другим. Жены жаловались на побои мужей, говоря о “впадении в меланхолию” и изнурении ею, выходом из которой мог быть только развод. ${ }^{100}$ На своих безумных детей жаловались родители и просили “исправить" разум бесчинного потомка монастырской ссылкой.

Самым громким бракоразводным процессом петровского времени был развод Павла Ягужинского со своей супругой Анной Федоровной, в котором немаловажное значение имела “меланколия." В 1722 году обер-прокурор Синода Ягужинский подал доношение на Анну Федоровну, обвиняя ее в различных “противностях" и непотребствах. Он требовал развода, говоря о том, что Анна вредит чести его имени. К этим бесчинствам относилось и богохульство: Анна ломала иконы и кидала на пол кресты. За подобные богохульные проступки, Анну ждало бы суровое телесное наказание, которое бы нанесло большой урон чести Ягужинского. Однако, Анна показала, что проступки она совершила будучи в меленхолии, которой она страдает с 1721 года после переезда в Петербург, тоскуя в отсутствии мужа и детей от одиночества. Синод постановил, “понеже показала, что чинила то в меланхолии и беспамятстве ... от достойного наказания ее оное (беспамятство) выключает. токмо простых продерзостей отнюдь оставить нравы не допускают, послать ее в Федоровский, что в Переяславль Залесском монастырь." Это, на мой взгляд, первый зафиксированный в документах случай, когда меланхолия служила смягчением приговора и санкционировалась ссылкой в монастырь. ${ }^{101}$ Анна содержалась в монастыре до своей смерти в 1733 году: средства на ее охрану и кошт предоставил ее бывший супруг.

Для Ягужинского диагноз меланхолии был подходящим предлогом защиты чести: его жена могла избежать позорящего его фамилию телесного наказания, а он сам мог объяснить высшему свету непотребное поведение его жены ее безумием. Болезнь, настоящая или вымышленная, сделала из преступницы больную.

Челобитные родителей на взрослых детей - довольно частое явление. Невозможность повлиять на бесчинное поведение сына или дочери и опасения потери благосостояния представляли вмешательство властей последним выходом из тяжелой ситуации. Так, в 1773 году, княгиня Анна Кантакузи просила в Сенате отправить в какой-либо монастырь своего сына, отставного прапорщика гвардии Преображенского полку, князя Авраама Кантакузи, который, “быв немалое время

\footnotetext{
100 “каковых мужа моего несносных побоев и изнурения впала я в болезнь и одержима была меленколиею.” По прошению Марфы Кирилловой о разводе ее с мужем коллежским асессором. РГИА, Ф. 796, оп. 41, д. 241, 1760 г. (RGIA, F. 796, op. 41, d. 241, 176o g.).

${ }^{101}$ РГИА, Ф. 796, оп.3, д. 997, л. 123. (RGIA, F. 796, ор. 3, d. 997, 1. 123).
} 
в болезни лишился несколько ума почему и делал разные непристойности." Через несколько месяцев княгиня просила о возвращении сына к ней в дом, уверяя, “что сын ее ... противное свое состояние поправил и пришел в хороший порядок.” В 1777 году по просьбе своего отца в Спасо-Евфимиев монастырь “для воздержания от сумасбродства" был заключен асессор Петр Булгаков “за пьянство, бой отца и матери и похвальбу зарезать отца." ${ }^{103}$ В монастыре Петр содержался за счет своего отца. В 1786 году по прошению князя Василия Голицына за буйственные поступки в монастырь был направлен его сын, князь Дмитрий Голицын. ${ }^{104}$

Феномен заключения по просьбе родственников был широко распространён во всей Европе. Простой люд пользуется возможностью письменных петиций в ситуациях, когда решить проблемы своими силами не представляется возможным. Во Франции XVIII века - это известные lettres de cachet, инициирующие заключение членов семьи в исправительных учреждениях. В Голландии к концу XVII века возникли частные betterhuizen, исправительные дома. В Германии, по личным обращениям производилась ссылка в Zuchthaus - смесь рабочего и исправительного дома. ${ }^{105}$

В России домами смирения служили монастыри, и, очевидно, что эту роль они продолжили исполнять и после учреждения т.н. “смирительных домов” по ст. 391 Учреждения для управления губерний 1775 года. ${ }^{106}$ Родители должны были направлять прошение о заключении в смирительный дом в Приказ общественного призрения. Тем не менее, практика доношений в Синод и другие традиционные инстанции (архиерейский дом, местные правления и Сенат) продолжилась, как продолжилась и практика смирения сумасбродных в монастырях по просьбе родственников.

\section{Исправление меланхолии: Молитва и труд в монастыре}

Каким образом практики монастырского заключения должны были способствовать исправлению меланхоликов? Прежде всего, монастыри следовали общехристианскому завету ora et labora: кроме молитвы и божественного

\footnotetext{
${ }_{102}$ РГАДА, Ф. 1203, оп.1, д. 19257 (1773 год). (RGADA, F. 1203, op. 1, d. 19257 (1773 god).

${ }^{103}$ РГАДА, Ф.7, оп.2, д. 2494, л. 171. (RGADA, F. 7, ор. 2, d. 2494, 1. 171).

${ }^{104}$ там же, л.205. (Tam zhe, 1. 205).

${ }^{105}$ В немецких землях, например в Саксонии родители обращались в органы полиции и юстиции земельного правительства. Bretschneider, Kinder und Jugend im Zuchthaus, 381. Во Франции Lettre de cachet направлялись первоначально к лейтенанту полиции, ответственному за округ. Он руководил расследованием и часто сам решал о заключении. Arlette Farge \& Michel Foucault, Familiäre Konflikte. Die "Lettres de cachet" aus den Archiven der Bastille im 18. Jahrhundert (Frankfurt a.M.: Suhrkamp, 1989), 11, 19.

106 Для них специально оговаривалось: “Смирительный дом установляется ради таких людей обоего пола, которые непотребного и не воздержного жития, яко 1. сыновья или дочери, кои родителям своим не послушны, или пребывают злого жития, или ни к чему доброму не склонны, Сосланных в смирительный дом по прошению родителей, родственников, помещиков или хозяев, сами родители, родственники, помещики и хозяева должны снабдевать содержанием, без чего смирительный дом сосланных не принимает или принятых освобождает.” См. текст Указа в Учреждении: https://constitution.garant.ru/history/act1600-1918/2350/. Учреждение, “Дела касающияся до таковых преступников,” 399. Цит. по https://constitution.garant.ru/history/act16001918/2350/. (Uchrezhdenie, "Dela kasaiushchiiasia do takovykh prestupnikov," 399. Tsit. po https://constitution.garant.ru/history/act16oo-1918/2350/). Однако мы не встречаем просьб родителей о заключении нерадивых отпрысков в смирительные дома, как это было положено Указом 1775 года.
} 
песнопения, труд являлся главным элементом содержания “под началом” до последней трети XVIII века. В тягчайшие труды отправляли не только обычных узников, осужденных по уголовным делам, но и безумных. ${ }^{107}$

Труды в хлебне, мукосейные труды, труды в поварне являлись не только тяжелейшими видами работ в монастыре, они были и глубоко символичны. Работа в жаркой и душной поварне, квасоварне или хлебне может быть рассмотрена в контексте символики страданий и искупления грешной души, где хлебенная печь символизирует муки ада. ${ }^{108}$

Не удивительно, что труды, на которые определялись безумцы, часто заканчивались смертельными случаями. Самый известный случай произошел с дворцовым крестьянином Порецкой волости Данилой Ширяевым. В 1730 году по доношению матери он был отправлен по решению Сената и по определению Синода в Данилов монастырь “в тяжкие труды без послабления." Через некоторое время его перевели в Симонов монастырь, где его определили в квасоваренную работу. Здесь он „внезапно ввалился в квасной котел и в кипятке обварился и от того умре."109

В 1729 году “меланхолика” Федора Алексеева, попа села Лозовец, сослали в Троице-Сергиев монастырь в мукосейные труды. Он был взят в Преображенский приказ по доносу на то, что провозглашал не по форме титулование Его Императорского Величества. Перед судом ему, очевидно, помог самодиагноз меланхолии для смягчения приговора. ${ }^{10}$ Это - одна из немногих историй ссыльных меланхоликов, которая заканчивается освобождением из монастырского заключения. Через два года, по просьбе жены Федор был освидетельствован братией монастыря, признан в совершенстве ума и освобожден. ${ }^{111}$

В практиках “исправления” близость сумасбродства и “пьянства” не может не бросаться в глаза. ${ }^{112}$ Местами надзора и исцеления опять становились монастыри, а “лекарством" - монастырский быт и церковное пение. Так, в 1728 году копиист синодальной канцелярии Василий Зеленин был отдан для исправления ума в Троице-Сергиев монастырь: родственники, духовники и соседи донесли на его неистовства и болезнь, хотя его начальник настаивал на том, что Зеленин всего лишь “многократно пьянствовал.” Уже через несколько месяцев пришедший в

\footnotetext{
${ }^{107}$ В 1728 году архимандрит Спасо-Евфимиева монастыря Питирим получил указ императора Петра Второго о сосланном к нему под начал крестьянине Василии Савельеве, “который впал в безумство." Его следовало содержать в монастыре и приводить ко всякому божественному пению, и, отдав "хлебенному монаху" под начал приставить к работе в хлебне. РГАДА, $\phi .1203$, оп.1, вяз. 227, д.160, 1728 год. (RGADA, f. 1203, ор. 1, viaz. 227, d. 160, 1728 god.).

${ }_{108}$ См. С. Шаляпин, “О символизме средневековой церковно-пенитенциарной практики," Актуальные проблемы правовой науки: Межвузовский сборник научных трудов, вып.2. (Архангельск: Издательство ПГУ, С, 2002), 59-73. (S. Shaliapin, "O simvolizme srednevekovoi tserkovno-penitentsiarnoi praktiki," Aktualynye problem pravovoi nauki: Mezvuzovskii sbornik nauchnykh trudov, vyp. 2 (Arkhangel'sk: Izdatel'stvo PGU, S, 2002), 59-73).

${ }^{109}$ ОДДС, т. 10, нр. 260. 19 июня 1730. (ODDS, t. 10, nr. 260. 19 iiunia 1730.).

${ }^{110}$ В Преображенском приказе поп Федор показал, что он меланхолик. РГИА, Ф. 796, оп. 1о, д. 340. (RGIA, F. 796, op. 10, d. 340). По ведению Сената при котором прислан для отсылки в монастырь меланхолик Роменского уезду села Лозовец поп Федор Алексеев. 10 сентября 1729.

"111 Там же. (Tam zhe).

112 Шаляпин и Плотников, Особенности заключения умалишенных преступников в России, 34. (Shaliapin i Plotnikov, Osobennosti zakliucheniia umalishennykh prestupnikovv Rossii, 34.).
} 
разум Зеленин был возвращен на службу. ${ }^{113}$ В Петербурге нередки были случаи отсылки солдат и моряков в Александро-Невский монастырь “для воздержания от пьянства." 114

Мы не можем точно сказать, чем являлся тяжкий труд в русских монастырях наказанием за проступки, совершенные в безумии, или способом дисциплинирования и исправления человека. Но нельзя не отметить важный факт, что практики воздействия на безумных не отличались от практики воздействия на тех, кто посылался в монастырь за пьянство или на покаяние за совершенный проступок (будь то блуд, прелюбодеяние или неумышленное убийство). "Исправление ума" было способом излечения человека, в процессе которого он раскаивался от своих мыслей и слов ${ }^{115}$ и улучшал поведение. Итак, “исправившийся" человек должен прежде всего был признать свои проступки и раскаяться в них - тогда он мог быть освобожден.

В этом значении труда - схожесть с европейскими домами исправления, использующими те же практики труда и религиозного увещевания. Созданные в упраздненных монастырях (также как и госпитали), они продолжали оставаться полу-монастическими учреждениями, следующими идее ora et labora. В Европе раннего нового времени труд служил исправлению человека от его “греховного” поведения, способом преодоления как безумия, так и лености, скуки. Элемент социальной полезности дополнил здесь понимание меланхолического уныния как грех acedia. Известнейший труд Фуко “История безумия” акцентирует на этом дискурсе особое внимание: также как бездомные, нищие и инвалиды, безумные были подвержены воздействию в традициях общего преследования праздности в учреждениях типа Hôpital General. Психическое заболевание стало рассматриваться как моральный дефицит, исправляемый тяжелым трудом. ${ }^{116}$ “Конфронтация с собственной совестью” - так определил функцию голландских betterhuizen XVIII века Питер Шпиренбург. ${ }^{117}$

\section{История неудачи? Религиозная меланхолия}

В 1738 году 18-летний матрос Никифор Куницын, будучи писарем в своем полку, за ошибку при переписывании был наказан ударом по голове, “от чего пришел в великое сумнение и учинилось ему затмение ума.”18 Будучи в затмении ума он писал письма “князю тьмы," прося его об обогащении. Смертная казнь, которая полагалась за богохульства, была заменена на вечные труды в Соловецком монастыре, куда он и прибыл в 1744 году. Здесь до 1765 года Куницын вел, судя по рапортам, правильную для христианина жизнь, ходил в церковь и “на труды.” Для его наставников и караула осталось, однако незамеченным, что Куницын находил

\footnotetext{
${ }^{113}$ ОДДС, т. 8, n. 433 от 17 июля 1728 (1728). (ODDS, t. 8, n. 433 ot 17 iiulia 1728 (1728).).

114 Так, в 1742 году по сенатскому ведению были отосланы офицеры морского флота в АлександроНевский монастырь “для воздержания от пьянства.” Через месяц монастырь отчитывается, что никакого пьянства от офицеров не усмотрено, они находятся в трезвости, в добропорядочном житии и в церковь божию на молитву ходят. РГИА, ф. 796, оп. 23, д. 37. 1742 г. (RGIA, f. 796, op. 23, d. 37.1742 g.).

115 Это отмечает и Янгулова, Институционализация психиатрии, 158. (Iangulova, Institutsionalizatsiia psikhiatrii, 158).

${ }^{116}$ Foucault, Wahnsinn und Gesellschaft, 89.

${ }^{117}$ Spierenburg, The Prison Experience.

${ }^{118}$ ОДДС, т. 22. нр. 1115, стб. 784 (1742 год). (ODDS, t. 22. Nr. 1115, stb. 784 (1742 god.).
} 
время для изучения библейских книг и писания писем в Синод и на имя императрицы. Писанные им предложения по исправлению священных книг указывали на ошибки и противоречия в Писании, а также критиковали православные обычаи. Он просил высоких иерархов Синода высказать свое мнение на его критику Писания и разрешить его от “великого сумнения." За писание писем во власть Никифор был наказан телесным наказанием перед собравшейся братией: до конца своей жизни он должен был оставаться в монастыре в трудах. ${ }^{119}$

Надо сказать, что матрос не был одинок в своем “сумнении” в православной вере. Его компаньон по заключению в Соловецком монастыре, новокрещенный еврей Афанасий Кискин был сослан в 1755 году за то, что, будучи в ПафнутьевБоровском монастыре, “впал в великое отчаяние” от того, что не нашел он правды в “вашей христианской вере," беспамятство. В беспамятстве он сломал крест и кричал богохульные слова, так как не получал ответа архимандрита на свои сомнения.

В обоих случаях отчаяние монастырских узников - не медицинская, а скорее религиозная проблема. “Обмирщение” монастырского подначальства, ${ }^{121}$ т.е. неопределенность срока заключения, содержание, напоминающее скорее тюремное, чем “начал” мудрого старца приводило к отчаянию многих.

Отказ от религиозного определения, оккультизм, сомнение в вере - все это признаки “религиозной меланхолии,” которую можно встретить в Европе раннего нового времени. ${ }^{122}$ В борьбе за свободу веры в период реформации и контрреформации отрицание или отступление от веры тяжело каралось. По словам автора “Анатомии Меланхолии," Роберта Бертона, испанская инквизиция является выражением того психического террора, который приводит к меланхолической растерянности. ${ }^{123}$ Бертон представлял меланхолию как выражение католической или пуританской строгости. ${ }^{124}$ Отчаяние приводит к кризису веры: отчаявшийся человек больше не доступен богу. ${ }^{125}$

Заключенные в монастырской ссылке подвержены отчаянию. Не удивительно, что узники представляли себя жертвами уныния, когда заторможенность действий сменялась разрушительным потенциалом. Для религиозной меланхолии типичны мучения веры, отчаяние, уныние и мысль о суициде. Это понятие близко средневековым трактатам о грехе акедии, которую Хильдегарда Бингенская, например, связывала с меланхоличным темпераментом. Таким

\footnotetext{
${ }^{119}$ РГАДА, ф. 1201, оп. 2, д. 850 (1765 год). (RGADA, f. 1201, op. 2, d. 850 (1765 god.).

${ }^{120}$ РГИА, ф. 796 об. 34, д. 90 (1753 год). (RGIA, f. 796 ob. 34, d. 90 (1753 god.).

121 См. Шаляпин, Церковно-пенинтенциарная система России, 218. (Shaliapin, Tserkovnopenitentsiarnaia Sistema $v$ Rossii, 218.).

${ }^{122}$ Tersch, Melancholie in österreichischen Selbstzeugnissen des Späthumanismus, 144-146. О религиозной меланхолии и ее врачевании трудом писал и Роберт Бертон, см. об этом Старобински, Чернила, 57. (Starobinski, Chernila, 57).

${ }^{123}$ Tersch, Melancholie in österreichischen Selbstzeugnissen des Späthumanismus, 144. Издание цитируемое Тершом: Robert Burton, The Anatomy of Melancholy, eds. Thomas C. Faulkner, Nicolas K. Kiessling, Rhonda L. Blair, 3 vols. (Oxford: Clarendon Press, 1989-1994). (Здесь: vol. 1, 343.)

${ }^{124}$ Ibid., 145.

${ }^{125}$ По мысли Лютера отчаяние открывает путь дьяволу к душе человека. В то же время меланхолия является в том числе и продуктивным религиозным кризисом. Так, в религиозных кризисах человек сомневающийся утверждается в вере. Печаль духа лучше для усиления веры, чем положительные события. Церковные песни должны были прогнать отчаяние и меланхолию. Ibid., 146.
} 
образом, о каком-либо “успехе” исправления меланхоликов в монастырях не может быть речи. Монастырская по форме, мирская по содержанию практика монастырского заточения порой лишь усугубляла отчаяние узников.

\section{Заключение}

В России XVIII века меланхолия стала распространенным объяснением многих медицинских, религиозных и поведенческих феноменов, влекущих заточение в монастырь. Тем временем, не было создано четкого определения понятия и однозначных модельных практик обращения с меланхолией. Состояние психической вменяемости стало предметом внимания в судебных процессах, в которых все чаще консультировались медики и/или духовники. Меланхолия как и более широкий феномен безумия, стала определяться как болезненные проявления, вызванные внешним физическим воздействием (как удар по голове), или психические переживания (долгое одиночество, тоска) или чрезмерное потребление алкоголя. Меланхолия как болезнь, могла оправдать обвиняемого и смягчить его наказание.

Тем не менее, научный и медицинский язык медиков еще не замещает окончательно теологического объяснения безумия. Язык греха и проделок беса в отношении безумных продолжал оставаться в силе: нехристианское поведение, нарушение божественных правил, греховная жизнь могут привести к болезни, а дьявол может завладеть душой и телом грешника.

Религиозная традиция обращения с безумными сохранилась и после секулярных реформ петровского и екатерининского времени. Как уже несколько веков в Западной Европе, монастыри все чаще рассматриваются как благотворительные учреждения, которые должны проявлять заботу о бедных и больных. Если госпитали в Европе, созданные в упраздненных монастырях, продолжали оставаться полу-монастическими учреждениями, то и в России действующие монастыри соединили в себе различные функции, полезные для политики “общего блага.” Это касалось как обеспечения социальной безопасности (изоляция безумных), так и “исправления” непристойного поведения, и наказания за богохульство.

Ссылка была решением многих проблем не только для государства, но и для подданных. XVIII век - время широкого использования практики доношений на членов семьи о непотребном поведении, когда единственным решением семейных конфликтов могло стать заключение troublemaker под караул. Монастырские практики заключения особенно не интересовались точным диагнозом медиков медицинский язык здесь не использовался. В монастыре “лечили” церковным пением и трудом. Таким образом, религиозная традиция обращения с безумными продолжала оставаться в силе, а реформы Петра и Екатерины Великой не изменили мышления общества. Так, ссылка в монастырь продолжилась и после учреждения смирительных домов и долгаузов. 